\title{
EXTERNAL DEVELOPMENT OF THE ENTOMOPATHOGENIC FUNGI Beauveria bassiana AND Metarhizium anisopliae IN THE SUBTERRANEAN TERMITE Heterotermes tenuis
}

\author{
Alcides Moino Jr. ${ }^{1 *}$; Sérgio Batista Alves²; Rogério Biaggioni Lopes²; Pedro Manuel Oliveira \\ Janeiro Neves ${ }^{3}$; Roberto Manoel Pereira ${ }^{4}$; Solange Aparecida Vieira ${ }^{2}$ \\ ${ }^{1}$ Depto. de Entomologia - UFLA, C.P. 37 - CEP: 37200-000 - Lavras, MG. \\ ${ }^{2}$ Depto. de Entomologia, Fitopatologia e Zoologia Agrícola - USP/ESALQ, C.P. 9 - CEP: 13418-900 - Piracicaba, SP. \\ ${ }^{3}$ Depto. de Agronomia - UEL, C.P. 6001 - CEP: 86051-970 - Londrina, PR. \\ ${ }^{4}$ USDA-ARS, CMAVE, 1600 SW 23rd Drive, Gainesville, FL 32604, USA. \\ *Autor correspondente <alcmoino@ufla.br>
}

\begin{abstract}
The subterranean termite Heterotermes tenuis is one of the main pests of sugarcane and eucalyptus in Brazil, and the use of entomopathogenic fungi, alone or associated to chemicals, is an efficient and environmentally favorable method for its control. Studies related to the fungal development on these insects are important due to the effect of insect behavior on entomopathogens. The objective of this work was to describe the external development of Beauveria bassiana and Metarhizium anisopliae on $\mathrm{H}$. tenuis using Scanning Electron Microscopy (SEM), determining the duration of the different phases of fungal infection. Two fixation techniques for preparing SEM samples were also evaluated. Worker specimens of $H$. tenuis were inoculated with a $1 \times 10^{9}$ conidia $\mathrm{mL}^{-1}$ suspension of the fungi and maintained at $25 \pm 1^{\circ} \mathrm{C}$ and $70 \pm 10 \%$ relative humidity. Insects were collected from 0 to 144 hours after inoculation and prepared on SEM stubs for each of the two fixation techniques. The results obtained with the two techniques were compared and duration of the different phases of the infection process were estimated from SEM observations and compared for three fungal isolates. $B$. bassiana and $M$. anisopliae have similar development cycles on the termite, but some important differences exist. The penetration, colonization and conidiogenesis phases are relatively faster for $M$. anisopliae than for $B$. bassiana, which results in a faster rate of insect mortality. The fixation technique with $\mathrm{OsO}_{4}$ vapor is suitable for preparation of insects to be used in SEM observation of the developmental stages of entomopathogenic fungi.
\end{abstract}

Key words: insecta, isoptera, microbial control, scanning electron microscopy

\section{DESENVOLVIMENTO DOS FUNGOS ENTOMOPATOGÊNICOS Beauveria bassiana E Metarhizium anisopliae NO CUPIM SUBTERRÂNEO Heterotermes tenuis}

\begin{abstract}
RESUMO: O cupim subterrâneo Heterotermes tenuis , uma das principais pragas da cana-de-açúcar e eucalipto no Brasil, e o uso de fungos entomopatogênicos, isoladamente ou associados a produtos químicos, é um método eficiente e ambientalmente seguro para seu controle. Estudos relacionados ao desenvolvimento fúngico nestes insetos são importantes devido ao efeito do comportamento dos insetos sobre entomopatógenos. O objetivo deste trabalho foi descrever o desenvolvimento de Beauveria bassiana e Metarhizium anisopliae sobre $H$. tenuis por meio da Microscopia Eletrônica de Varredura (MEV), determinando a duração das fases de infecção fúngica. Também foram avaliadas duas técnicas de fixação para o preparo de amostras para MEV. Operários de $H$. tenuis foram inoculados com suspensões fúngicas de $1 \times 10^{9}$ conídios $\mathrm{mL}^{-1}$ e mantidos a $25 \pm 1^{\circ} \mathrm{C}$ e umidade relativa de $70 \pm 10 \%$. Foram coletados insetos de 0 a 144 horas após a inoculação e preparados pelas duas técnicas de fixação. Foram comparados os resultados obtidos com as duas técnicas e estimadas e comparadas as durações das fases do processo de infecção para três isolados fúngicos por meio de observações em MEV. B. bassiana e $M$. anisopliae têm ciclos de desenvolvimento semelhantes sobre $H$. tenuis, mas algumas diferenças importantes existem. As fases de penetração, colonização e conidiogênese são relativamente mais rápidas para $M$. anisopliae que para $B$. bassiana, o que resulta em uma taxa mais rápida de mortalidade do inseto. A técnica de fixação com vapor de $\mathrm{OsO}_{4}$ é satisfatória para preparação de insetos para observação do desenvolvimento de fungos entomopatogênicos em MEV.

Palavras-chave: insecta, isoptera, controle microbiano, microscopia eletrônica de varredura
\end{abstract}

\section{INTRODUCTION}

The subterranean termite Heterotermes tenuis (Hagen) is one of the main pests of sugarcane and eucalyptus in Brazil, and its importance has increased considerably after the use of organo-clorinated insecticides was banned in the middle of the 1980's. The use of entomopathogenic fungi, alone or associated to new chemical active ingredients, has proved to be an efficient and environmentally favorable method for the 
control of the termite. Beauveria bassiana (Bals.) Vuill. and Metarhizium anisopliae (Metsch.) Sorok. are two of the most well studied entomopathogenic fungi (Fernandes \& Alves, 1991, 1992; Almeida \& Alves, 1995, 1996; Almeida et al. 1998; Moino Jr. \& Alves, 1998).

Studies related to the duration of the different phases of fungal development on insects are relatively rare. This is especially important due to the effect of insect behavior on entomopathogens (Bao \& Yendol, 1971; Hanel, 1982). These studies can be conducted using bioassays and observation of the different phases of fungal infection, through scanning electron microscopy (SEM) (Neves et al., 1996). The method used in the preparation of SEM samples should avoid damage to the insect and fungal structures involved in penetration, especially when the objective is to document the infection process (Quattlebaum \& Carner, 1980; Hunt et al., 1984).

The objective of this work was to describe the external development cycle of $B$. bassiana and $M$. anisopliae on $H$. tenuis using SEM, and to determine the duration of the different phases of fungal infection. Two fixation techniques for preparing SEM samples were evaluated.

\section{MATERIAL AND METHODS}

Worker specimens of $H$. tenuis, collected on cardboard traps (Termitrap ${ }^{\circledR}$ ) in an area of sugarcane production (Piracicaba, SP - Brazil), were transferred to plastic petri plates $(6 \times 1.5 \mathrm{~cm})$, lined with filter paper. Termites were inoculated with $0.1 \mathrm{ml}$ of a suspension (1 $\times 10^{9}$ conidia $\mathrm{mL}^{-1}$ ) of $B$. bassiana (isolates 447 or 634 ) or $M$. anisopliae (isolate E-9). The fungal strains, obtained from the bank of entomopathogens at the Insect Pathology and Microbial Control Laboratory (Entomology Sector - USP/ESALQ), were applied with a Paasche airbrush sprayer operated with a pressure of $1,47 \mathrm{MPa}$. Ten plates with 20 insects/plate were used for each one of the fungal strains, maintained at $25 \pm 1^{\circ} \mathrm{C}$ and $70 \pm 10 \%$ relative humidity.

Ten insects were removed from the plates 0,6 , $12,24,48,72,96,120$ and 144 hours after inoculation. The insects were killed in Petri dishes with ethyl ether and mounted on SEM stubs. Two stubs with five insects each were prepared for each sampling time for each of the two fixation techniques used: Osmium Tetroxide $\left(\mathrm{OsO}_{4}\right)$ fixation, and Glutaraldehyde/OsO $\mathrm{O}_{4}$ /Sodiumcacodilate buffer fixation.

For the first fixation technique, the specimens were exposed to $\mathrm{OsO}_{4}$ vapor for 48 hours in a hermetically closed plastic container with a glass Petri dish containing a liquid film of $\mathrm{OsO}_{4}$. After fixation, the insect stubs were dried for 72 hours in a glass desiccator with silica gel (relative humidity at $0 \%$ ). The last stage of preparation was the gold-palladium coating in a Balzers Evaporator, MED 010, for 120 seconds.
For fixation in Glutaraldehyde/OsO $\mathrm{O}_{4} /$ Sodiumcacodilate buffer, the insects were fixed by immersion for 6 hours in $4 \%$ glutaraldehyde with a $0.2 \mathrm{M} \mathrm{pH} 7.2$ sodium-cacodilate buffer. Specimens were then fixed in $1 \% \mathrm{OsO}_{4}$ in a $0.1 \mathrm{M} \mathrm{pH} 7.2$ sodium-cacodilate buffer for 1 hour. Fixation and dehydration were performed in plastic Ependorff tubes.

After fixation, specimens were dehydrated in $30,50,70,90$, and $100 \%$ acetone series. The insects were finaly washed three times in a $100 \%$ acetone solution. The critical point during drying when using $\mathrm{CO}_{2}$ was followed in a Balzers, CPD 030. The insects were then mounted on stubs and coated with goldpalladium as previously described. As in the previous technique, two stubs with five insects each were prepared for each sampling time. Only isolates 634 ( $B$. bassiana) and E-9 ( $M$. anisopliae) were used for this technique.

The insects were observed with a Zeiss, DMS 940-A scanning electron microscope, and the results obtained with the two preparation techniques were compared. Durations of the different phases of the infection process were estimated from SEM observations and compared for the three fungal isolates.

\section{RESULTS AND DISCUSSION}

Fixing insects in glutaraldehyde and $\mathrm{OsO}_{4}$ was more efficient in preserving the characteristics of both insects and fungi when compared to the fixation technique in $\mathrm{OsO}_{4}$ vapor only. The fungal structures were well preserved in the specimens fixed with glutaraldehyde technique (Figure $1 \mathrm{~A}, \mathrm{~B}, \mathrm{C}$ ), whereas with the osmium vapor technique, the fungal conidia became wrinkled and contracted (Figure $1 \mathrm{D}, \mathrm{E}, \mathrm{F}$ ). The insect body parts with stronger cuticle, such as the head, were less susceptible to alterations caused by the fixation technique. Thus, when the objective of the study is the quantification or visualization of pathogen structures in certain areas of the insect body, as in the present study, the osmium vapor technique can be used, because of its lower cost and degree of difficulty than the glutaraldehyde technique. Also, the $\mathrm{OsO}_{4}$ technique does not cause loss of the features to be studied. On the other hand, when more detailed characteristics are to be observed, as in taxonomic studies, the glutaraldehyde technique is preferable, because the aesthetic results are better.

In the present study, observation of germination and penetration of the conidia was performed on specimens fixed by the osmium vapor technique, which allowed the visualization of a greater number of structures than the glutaraldehyde technique. Despite the aesthetic advantages, the glutaraldehyde technique results in some loss of structures caused by immersion of the specimens in different liquids (acetone, glutaraldehyde, buffer, and osmium tetroxide). 

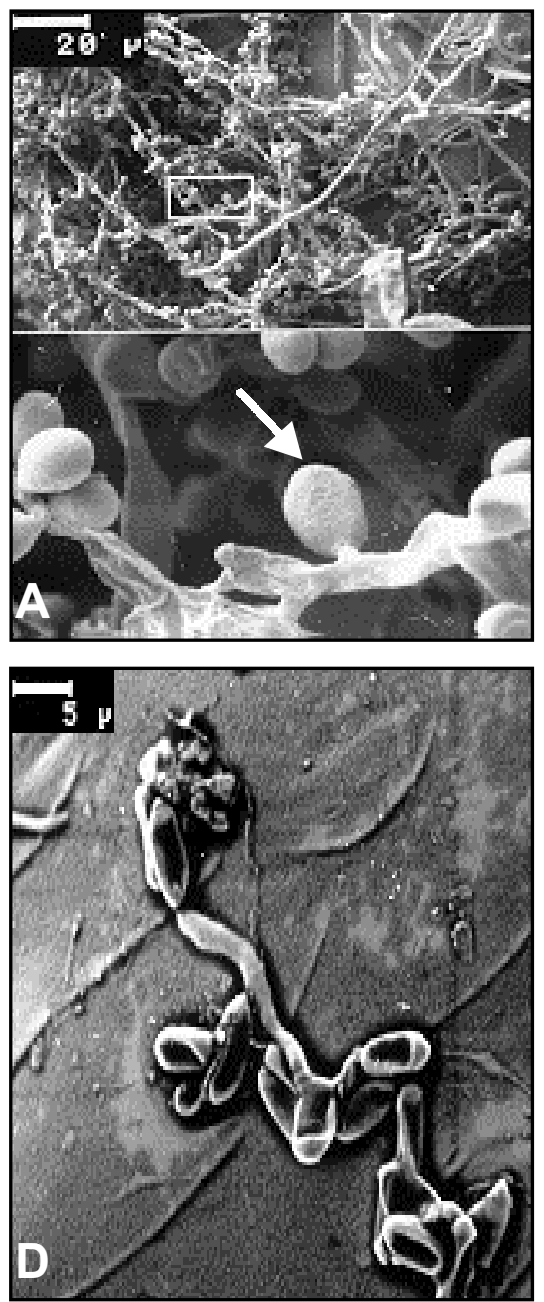
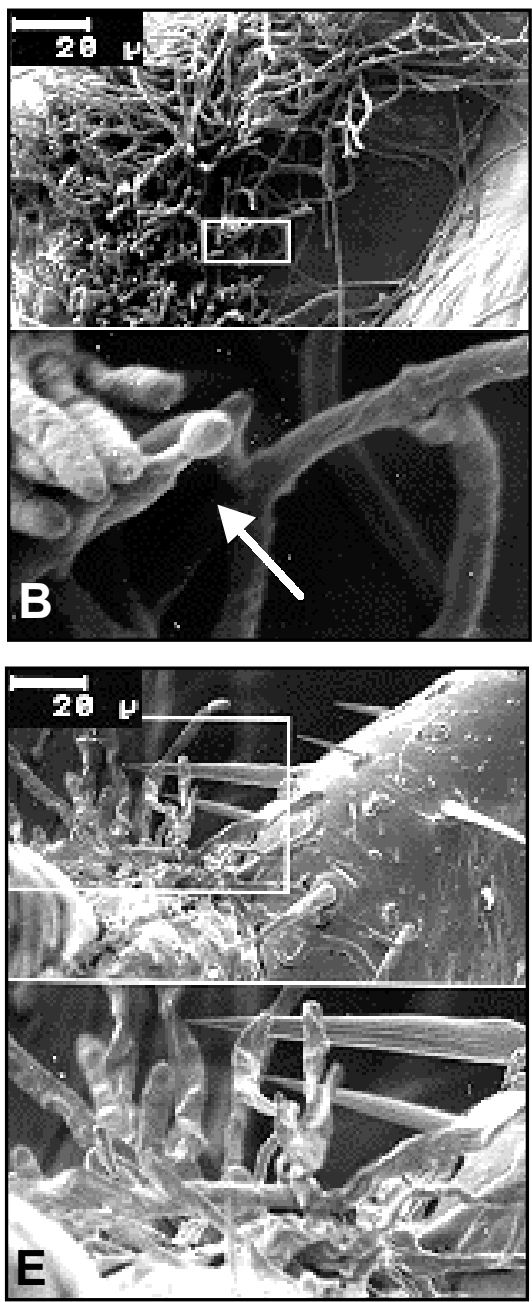
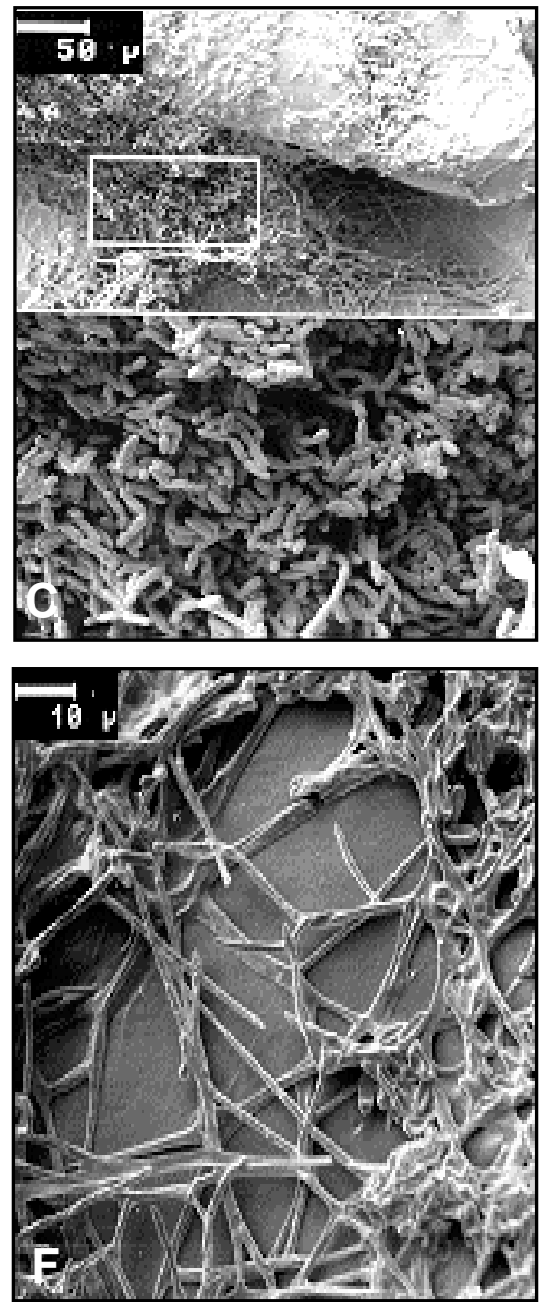

Figure 1 - Comparison between the fixation techniques used in preparing samples for scanning electron micrographs. Arrows showing the conidia state. A, B and C) Fixation with glutaraldehyde $+\mathrm{OsO}_{4}$ with sodium-cacodilate buffer (amplification of $4000 \mathrm{X}, 120 \mathrm{~h}$ after inoculation; 4000X, $96 \mathrm{~h}$, and $800 \mathrm{X}, 144 \mathrm{~h}$, respectively). D, E and F) Fixation with $\mathrm{OsO}_{4}$ vapor only $(2000 \mathrm{X}, 24 \mathrm{~h} ; 1000 \mathrm{X}, 96 \mathrm{~h}$ and $1000 \mathrm{X}, 120 \mathrm{~h}$, respectively).

Little variation in timing and duration of the phases was observed in the infection process for the 2 $B$. bassiana isolates. After application of $B$. bassiana, conidia adhered to the insect integument within 0 to 6 hours after inoculation (Figure $2 \mathrm{~A}, \mathrm{~B}$ ). Initiation of conidial germination happened between 12 and 48 hours after inoculation (Figure $2 \mathrm{C}$ ). The majority of the observed conidia were on the insect legs and head, but some conidia were also observed on the thoracic or abdominal segments (Figure $2 \mathrm{D}$ ). According to Boucias et al. (1996), B. bassiana formed germ-tubes and penetration structures between 12 and 24 hours after inoculation in Reticulitermes flavipes.

The formation of haloes around fungal conidia and germination tubes on the insect cuticle was observed with conidia adhesion and germination, but mainly during the penetration process (Figure $2 \mathrm{C}$ ). The occurrence of these haloes seems to be related to production and excretion of exoenzymes by the entomopathogen during the infective process. The enzymatic action of the fungus $B$. bassiana on Heliothis zea and Curculio caryae has been observed before with SEM (Smith et al., 1981; Champlin et al., 1981). The combination of proteolitic enzymes and chitinase produced by the fungal mycelium digest the insect cuticle, facilitating the penetration of the insect integument.

A thickening of the extremity of the germ-tube, characterizing the formation of appressoria, was observed during penetration by the fungus (Figure $2 \mathrm{D}$ ). In some areas such as the insect head, extensive growth of germ-tubes was observed, probably due to resistance to fungal penetration in these areas with more heavily sclerotized cuticle.

The phase of host colonization occurred between 72 and 120 hours, and most of the insects died between 72 and 96 hours after inoculation. The insects killed by $B$. bassiana had a pinkish coloration characteristic of oosporein activity, which is common in insects infected by this fungus (Vining et al., 1962).

Mycelial extrusion from the cadavers happened between 96 and 120 hours after inoculation, mainly in the 
intersegmental areas and, later, in areas with stronger cuticle, inducing complete cuticle degradation (Figure 2 F). The process of conidiogenesis occurred between 120 and 144 hours after inoculation (Figure 2 G). After 144 hours, the whole insect body was taken by $B$. bassiana conidia (Figure $2 \mathrm{H}, \mathrm{I}$ ). In a similar study with Cornitermes cumulans, greater amounts of mycelial extrusion points and conidiogenesis were observed in both insect legs and
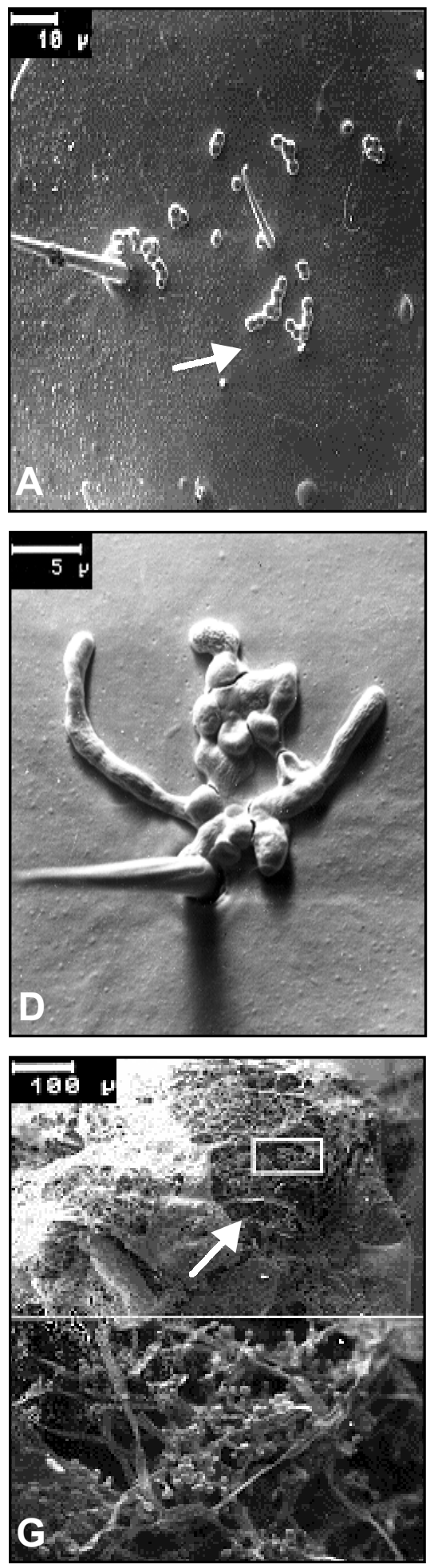
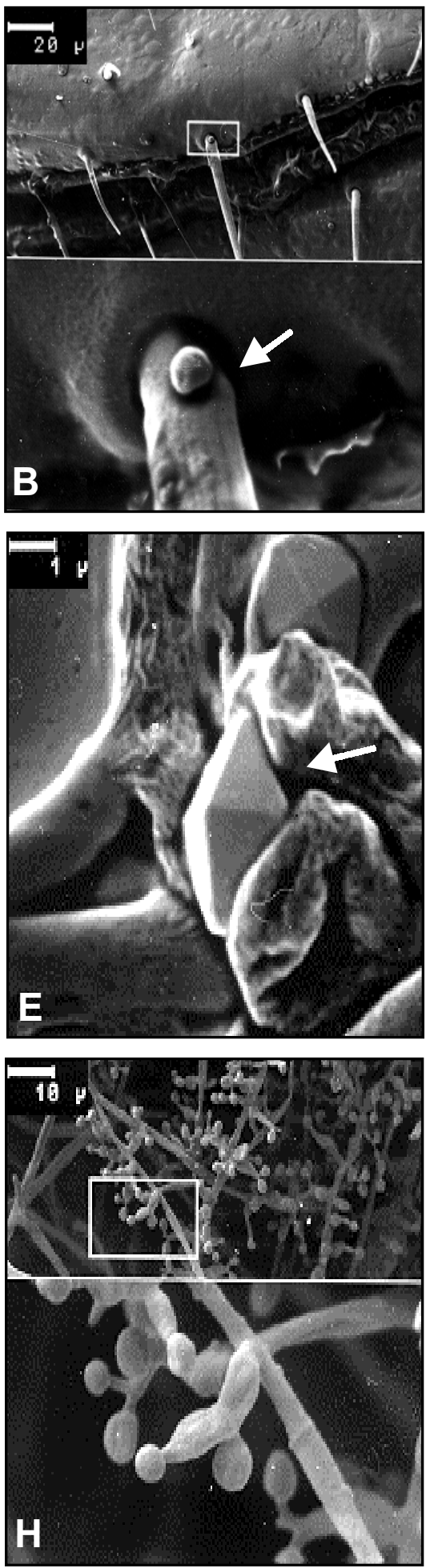
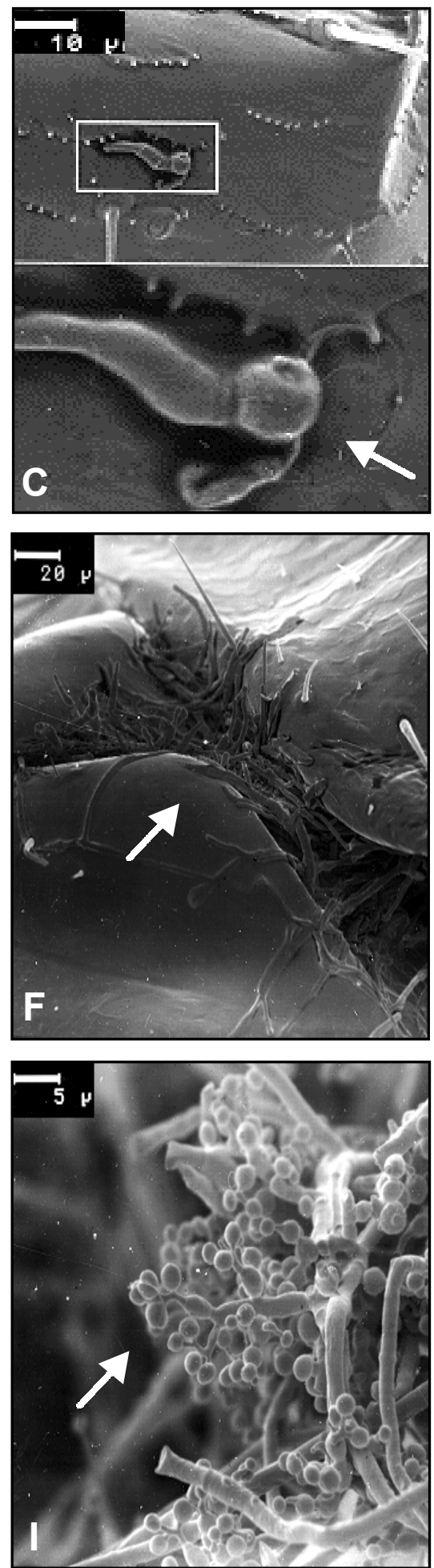

Figure 2 - Scanning electron microscope micrographs of the development of $B$. bassiana on $H$. tenuis. A) Conidia adhered to the tegument (1000X, $0 \mathrm{~h}$ after inoculation); B) Conidium adhered to the basis of a seta (2000X, $24 \mathrm{~h}$ ); C) Germinating conidium, with halo formation in the cuticle (4000X, $72 \mathrm{~h})$; D) Penetration of a germ-tube into the cuticle (3000X, $72 \mathrm{~h}$ ); E) Details of the bipiramidal crystals, possibly of oxalate (2000X, 96 h); F) Extrusion of the mycelium at intersegmental region (500X, 96 h); G) Conidiophore formation and conidiogenesis on the termite head, with degradation of the cuticle $(800 \mathrm{X}, 120 \mathrm{~h}) ; \mathrm{H}$ and I) Details of the conidiogenesis process (4000X and 2000X, $120 \mathrm{~h}$, respectively). 
head, and also in the membranous area of the labrum (Neves \& Alves, 2000). However, little conidiogenesis occurred on the abdomen. Unlike $H$. tenuis, and due to feeding habits and behavior of $C$. cumulans, this insect harbors a large number of microorganisms in its digestive system. These microorganisms may compete with the fungal pathogen, preventing optimal growth of the entomopathogen.
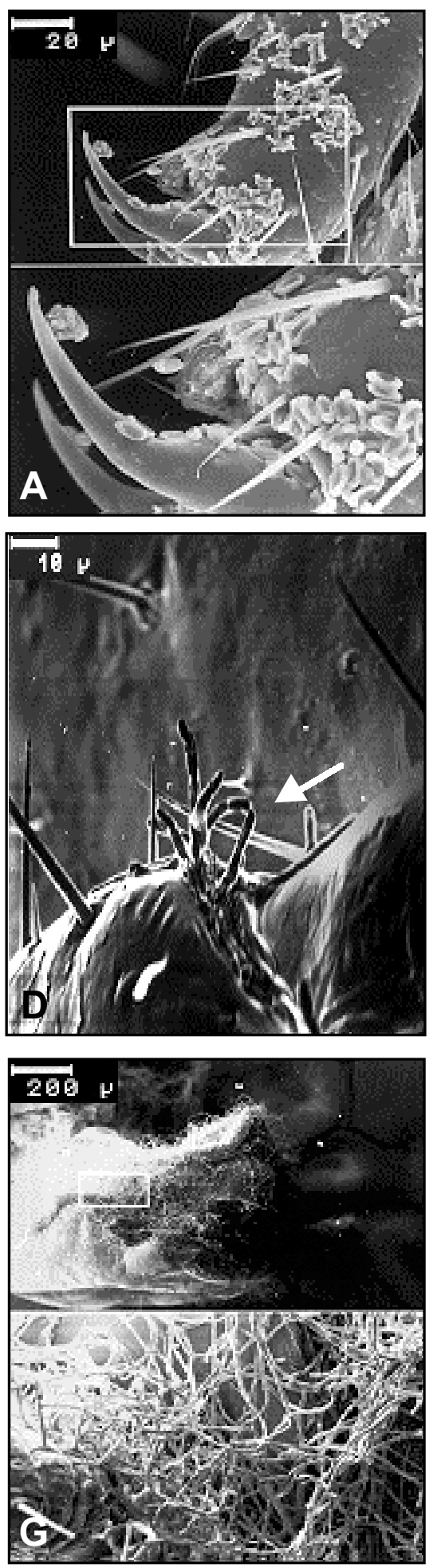
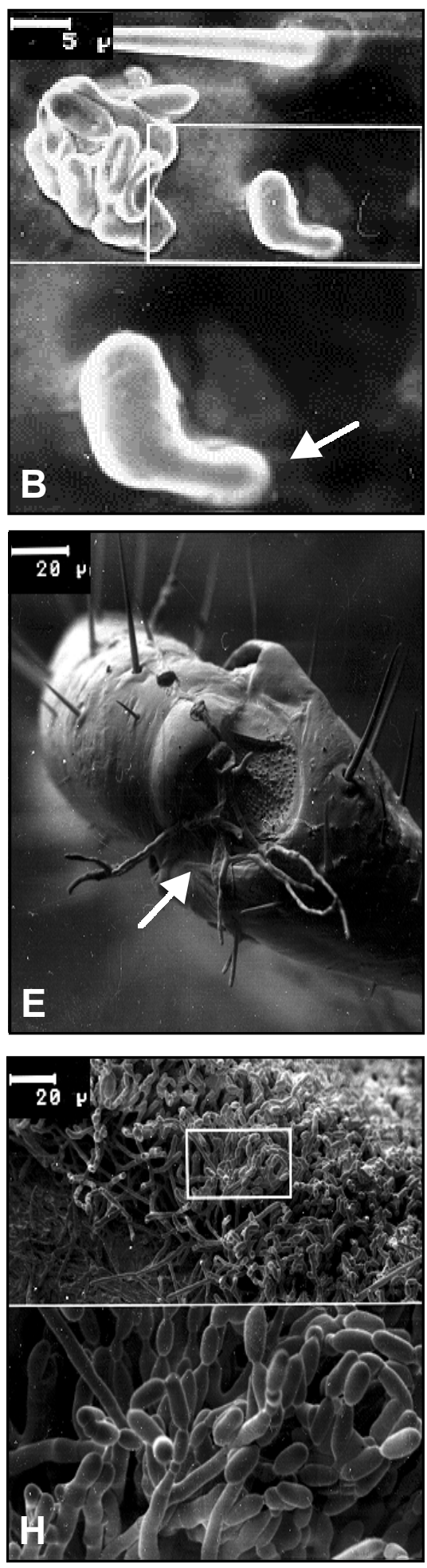
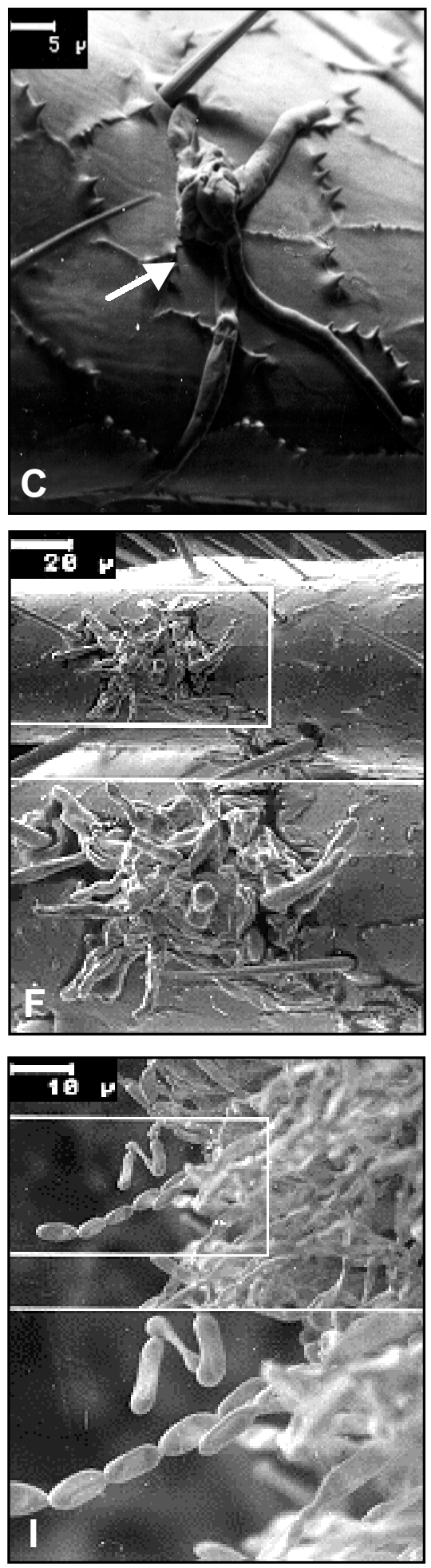

Figure 3 - Scanning electron microscope micrographs of the development of $M$. anisopliae on $H$. tenuis. A) Conidial adhesion to the tarsus (amplification of 500X, $0 \mathrm{~h}$ after inoculation); B) Germinating conidium, with penetration of the germ-tube (4000X, $24 \mathrm{~h}$ ); C) Growth of the germ-tube (2000X, $48 \mathrm{~h}) ; \mathrm{D}$ and E) Extrusion of the mycelium in intersegmental area (1000X, $48 \mathrm{~h}$ and $650 \mathrm{X}, 72 \mathrm{~h}$, respectively); F) Extrusion of the mycelium with degradation of the cuticle, in the tibia (1000X, $96 \mathrm{~h})$; G) Mycelium on the head (400X, 72 h); H) Conidiogenesis (2000X, 144 h); I) Detail of conidia chain (2000X, 120 h). 
Bipiramidal crystals, possibly of double oxalate of magnesium and ammonium, were observed encrusted on the integument of an infected insect, close to the area of the penetration of the germ-tubes (Figure $2 \mathrm{E}$ ). These crystals have been observed before in Bombyx mori (Amaral \& Alves, 1979) and their role in the pathogenicity of certain fungi is well documented in the literature (Roberts \& Krasnoff, 1998). These authors observed oxalate crystals on the surface of other insects killed by $B$. bassiana. Oxalic acid may be an important toxin in the haemolymph of insects infected by Beauveria species. The presence of these crystals is also common in the general cavity of mites (Tetranichidae and Eryophiidae) infected by Beauveria and Metarhizium strains (M.A. Tamai \& S.B. Alves, personal communication).

Observation of the development of $M$. anisopliae on $H$. tenuis revealed many similarities with the events reported for $B$. bassiana. Conidial adhesion to the integument happened immediately after inoculation and between 0 and 6 hours (Figure $3 \mathrm{~A}$ ), whereas conidial germination occurred between 12 and 24 hours after inoculation (Figure $3 \mathrm{~B}$ ). Penetration happened between 24 and 48 hours after inoculation. The average time for the penetration of $M$. anisopliae in $N$. exitiosus was 48 hours (Hanel, 1982).

Similar to $B$. bassiana, appressoria were also formed in $M$. anisopliae, characterized by a thickening of the extremity of the germ-tubes (Figure $3 \mathrm{~B}, \mathrm{C}$ ). This thickening is probably due to the translocation of the conidial cytoplasmatic content to facilitate the enzymatic synthesis necessary for the penetration phase. The formation of haloes on the insect cuticle at the germination and penetration points was also observed for $M$. anisopliae. An enzyme of the chymoelastase group (Pr1) has been implicated in cuticle degradation (St. Leger et al., 1988). According to these authors, $M$. anisopliae uses up to $78 \%$ of the protein synthesis for the production of this important enzyme in the process of penetration.

The colonization phase of $M$. anisopliae occurred between 48 and 72 hours after inoculation. M. anisopliae killed the insects 48 to 72 hours after inoculation, and the mycelium extrusion happened between 48 and 120 hours after inoculation. The mycelial extrusion was more intense for $M$. anisopliae than for $B$. bassiana. It was present initially, in the intersegmental areas (Figure $3 \mathrm{D}$, $\mathrm{E}$ ), and later in other areas (Figure $3 \mathrm{~F}$ ), resulting in a process of cuticle degradation along the whole body of the insect (Figure $3 \mathrm{G}$ ). Conidiogenesis happened between 96 and 144 hours after inoculation and, as happened for $B$. bassiana, the whole body was covered by $M$. anisopliae conidia 120 hours after inoculation (Figure $3 \mathrm{H}, \mathrm{I}$ ).

The timing for the different phases of the cycle of $B$. bassiana and $M$. anisopliae on $H$. tenuis are superimposed without a well defined separation
(Figure 4). The $M$. anisopliae isolate E-9 killed the insect faster than the $B$. bassiana isolates 447 and 634 , due to faster penetration and colonization. Almeida \& Alves (1995), selecting strains of entomopathogenic fungi for the control of $H$. tenuis, concentrated their efforts on the genus Beauveria, because the strains of $M$. anisopliae tested had low pathogenicity. Later, the $M$. anisopliae isolate 1037, from Solenopsis sp. fire ant, provided promising results in the control of $H$. tenuis and $C$. cumulans (Alves et al., 1997). The ongoing search for more pathogenic and virulent isolates of entomopathogenic fungi can profit from SEM studies, like the present study, that identify isolates with faster penetration and colonization.

Despite the standardization in fungal application, the inocula that reaches the insects are variable. This variation may interfere with the extent of colonization of the insect, the speed of mycelium growth, and conidiogenesis, resulting in differences in the mortality of the insects. The rates of conidia germination and

Beauveria bassiana (634 strain)

\begin{tabular}{|c|c|c|c|c|c|c|c|c|c|}
\hline & \multicolumn{9}{|c|}{ DURATION (HOURS) } \\
\hline Disease phases & 0 & 6 & 12 & 24 & 48 & 72 & 96 & 120 & 144 \\
\hline \multicolumn{10}{|l|}{ Adhesion } \\
\hline \multicolumn{10}{|l|}{ Germination } \\
\hline \multicolumn{10}{|l|}{ Penetration } \\
\hline \multicolumn{10}{|l|}{ Colonization } \\
\hline \multicolumn{10}{|l|}{ Insect death } \\
\hline \multicolumn{10}{|l|}{ Extrusion } \\
\hline Conidiogenesis & & & & & & & & & \\
\hline
\end{tabular}

Beauveria bassiana (447 strain)

\begin{tabular}{|c|c|c|c|c|c|c|c|c|c|}
\hline & \multicolumn{9}{|c|}{ DURATION (HOURS) } \\
\hline Disease phases & 0 & 6 & 12 & 24 & 48 & 72 & 96 & 120 & 144 \\
\hline Adhesion & & & & & & & & & \\
\hline Germination & & & & & & & & & \\
\hline Penetration & & & & & & & & & \\
\hline Colonization & & & & & & & & & \\
\hline Insect death & & & & & & & & & \\
\hline Extrusion & & & & & & & & & \\
\hline Conidiogenesis & & & & & & & & & \\
\hline
\end{tabular}

Metarhizium anisopliae (E-9 strain)

\begin{tabular}{|c|c|c|c|c|c|c|c|c|c|}
\hline & \multicolumn{9}{|c|}{ DURATION (HOURS) } \\
\hline Disease phases & 0 & 6 & 12 & 24 & 48 & 72 & 96 & 120 & 144 \\
\hline Adhesion & & & & & & & & & \\
\hline Germination & & & & & & & & & \\
\hline Penetration & & & & & & & & & \\
\hline Colonization & & & & & & & & & \\
\hline Insect death & & & & & & & & & \\
\hline Extrusion & & & & & & & & & \\
\hline Conidiogenesis & & & & & & & & & \\
\hline
\end{tabular}

Figure 4 - Duration, in hours, of the different developmental phases of $B$. bassiana and $M$. anisopliae on workers of the subterranean termite $H$. tenuis. 
penetration of the insect integument have been shown to be related to the virulence of the fungi and the susceptibility of the insect host (Pekrul \& Grula, 1979; Fargues, 1984). This study allowed the observation of the different phases of the disease cycle, and further demonstrated the importance of understanding these phases in selecting isolates for biological control of insects.

\section{ACKNOWLEDGMENTS}

To FINEP for the financial support and thank Dr. Elliot W. Kitajima and Ms. Silvania Machado (NAP MEPA - USP/ESALQ) for the opportunity and aid in using of the scanning electron microscope, and Dr. Daniela B. Lopes for improvements of the manuscript.

\section{REFERENCES}

ALMEIDA, J.E.M.; ALVES, S.B. Seleção de armadilhas para a captura de Heterotermes tenuis (Hagen). Anais da Sociedade Entomológica do Brasil, v.24, p.619-624, 1995

ALMEIDA, J.E.M.; ALVES, S.B. Mortalidade de Heterotermes tenuis (Hagen) atraídos por armadilhas com Beauveria bassiana (Bals.) Vuill. e imidacloprid. Anais da Sociedade Entomológica do Brasil, v. 25, p.507512, 1996.

ALMEIDA, J.E.M.; ALVES, S.B.; MOINO JR., A.; LOPES, R.B. Controle do cupim subterrâneo Heterotermes tenuis (Hagen) com iscas Termitrap impregnadas com inseticidas e associadas ao fungo entomopatogênico Beauveria bassiana (Bals.) Vuill. Anais da Sociedade Entomológica do Brasil, v.27, p.639-644, 1998.

ALVES, S.B.; ALVES, L.F.A.; LOPES, R.B.; VIEIRA, S.A. Isolado 1037 de Metarhizium anisopliae, promissor para o controle microbiano de insetos. In: CONGRESSO BRASILEIRO DE ENTOMOLOGIA, 16., Salvador, 1997. Resumos. Salvador: Sociedade Entomológica do Brasil, 1997. p.139.

AMARAL, E.; ALVES, S.B. Insetos úteis. Piracicaba: Livroceres, 1979. 188p.

BAO, L.; YENDOL, W.G. Infection of the eastern subterranean termite, Reticulitermes flavipes (Kollar) with the fungus Beauveria bassiana (Balsamo) Vuill. Entomophaga, v.16, p.343-352, 1971.

BOUCIAS, D.G.; PENDLAND, J.C.; FARIA, M.R. Insect defense mechanisms against microorganisms. In: SIMPÓSIO DE CONTROLE BIOLÓGICO, 6. Foz do Iguaçu, 1996. Anais; conferências e palestras. Foz do Iguaçu: EMBRAPA, 1996. p.249-257.

CHAMPLIN, F.R.; CHEUNG, P.Y.K.; PEKRUL, S.; SMITH, R.J.; BURTON, R.L.; GRULA, E.A. Virulence of Beauveria bassiana mutants for the pecan weevil. Journal of Economic Entomology, v.74, p.617-621, 1981.

FARGUES, J. Adhesion of the fungal spore to the insect cuticle in relation to pathogenicity. In: ROBERTS, D.W.; AIST, J.R. (Ed.) Infection processes of fungi; conference report. New York: The Rockfeller Foundation, 1984 p.90-110.
FERNANDES, P.M.; ALVES, S.B. Controle de Cornitermes cumulans (Kollar, 1832) (Isoptera: Termitidae) com Beauveria bassiana (Bals.)Vuill. e Metarhizium anisopliae (Metsch.) Sorok. em condições de campo. Anais da Sociedade Entomológica do Brasil, v.20, p.46-49, 1991

FERNANDES, P.M.; ALVES, S.B. Seleção de isolados de Beauveria bassiana (Bals.)Vuill. e Metarhizium anisopliae (Metsch.) Sorok. para controle de Cornitermes cumulans (Kollar, 1832) (Isoptera: Termitidae). Anais da Sociedade Entomológica do Brasil, v.21, p.319-328, 1992.

HANEL, $H$. The life cycle of the insect pathogenic fungus Metarhizium anisopliae in the termite Nasutitermes exitiosus. Mycopathologia, v.80, p.137-145, 1982.

HUNT, D.W.A.; BORDEN, J.H.; RAHE, J.E. Nutrient-mediated germination of Beauveria bassiana conidia on the integument of the Bark beetle Dendroctonus ponderosae (Coleoptera: Scolytidae). Journal of Invertebrate Pathology, v.44, p.304-314, 1984.

MOINO JR., A.; ALVES, S.B. Efeito de imicacloprid e fipronil sobre Beauveria bassiana (Bals.) Vuill. e Metarhizium anisopliae (Metsch.) Sorok. e no comportamento de limpeza de Heterotermes tenuis (Hagen). Anais da Sociedade Entomológica do Brasil, v.27, p.611-620, 1998.

NEVES, P.M.O.J.; ALVES, S.B. Grooming capacity inhibition in Cornitermes cumulans (Kollar) (Isoptera: Termitidae) inoculated with entomopathogenic fungi and treated with imidacloprid. Anais da Sociedade Entomológica do Brasil, v.29, p.537-545, 2000.

NEVES, P.M.O.J.; VIEIRA, S.A.; LOPES, R.B.; ALVES, S.B. Germinação, penetração e reprodução de Beauveria bassiana na broca do algodoeiro Eutinobothrus brasiliensis Hambleton, (Coleoptera: Curculionidae) observadas ao microscópio eletrônico de varredura (MEV). In: SIMPÓSIO DE CONTROLE BIOLÓGICO, 6., Foz do Iguaçu, 1996. Anais; sessão de pôsteres. Foz do Iguaçu: EMBRAPA, 1996. p.330.

PEKRUL, S.; GRULA, E.A. Mode of infection of the corn earworm (Heliothis zea) by Beauveria bassiana as revealed by scanning electron microscopy. Journal of Invertebrate Pathology, v.34, p.238-247, 1979.

QUATTLEBAUM, E.C.; CARNER, G.R. A technique for preparing Beauveria spp. for scanning electron microscopy. Canadian Journal of Botany, v. 58 p.1700-1703, 1980

ROBERTS, D.W.; KRASNOFF, S.B. Toxinas e enzimas de fungos entomopatogênicos. In: Alves, S.B. (Ed.) Controle microbiano de insetos. 2.ed. Piracicaba: FEALQ, 1998. p.967-986.

SMITH, R.J.; PEKRUL, S.; GRULA, E.A. Requirement for sequential enzymatic activities for penetration of the integument of the corn earworm (Heliothis zea). Journal of Invertebrate Pathology, v.38, p.335-344, 1981.

ST. LEGER, R.J.; DURRANDS, P.K.; CHARNLEY, A.K.; COOPER, R.M. Role of extracellular chymoelastase in the virulence of Metarhizium anisopliae for Manduca sexta. Journal of Invertebrate Pathology, v.52, p.285-293, 1988.

VINING, L.C.; KELLEHER, W.J.; SCHWARTING, A.E. Oosporein producion by a strain of Beauveria bassiana originally identified as Amanita muscaria. Canadian Journal of Microbiology, v.8, p.931-933, 1962.

Received January 24, 2001 